\title{
Effect of organic fungicides on sooty blotch, flyspeck and quality of apple cv. Banki grown in Rawalakot, Azad Jammu and Kashmir
}

\author{
Irfan Shehzad ${ }^{1}$, Mehdi Maqbool ${ }^{1 *}$, Noosheen Zahid ${ }^{1}$, Syed Zulfiqar Ali \\ Shah $^{1}$, Muhammad Jamil Ahmed ${ }^{1}$, Abdul Hamid ${ }^{1}$, Abid Yaqoob ${ }^{1}$ and \\ Muhammad Ahmed Shehzad ${ }^{2}$ \\ 1. Department of Horticulture, Faculty of Agriculture, University of Poonch Rawalakot, Azad Jammu and Kashmir- \\ Pakistan \\ 2. Department of Statistics, Bahauddin Zakariya University, Multan-Pakistan \\ *Corresponding author's email: mehdimaqbool@yahoo.com \\ Citation \\ Irfan Shehzad, Mehdi Maqbool, Noosheen Zahid, Syed Zulfiqar Ali Shah, Muhammad Jamil Ahmed, Abdul Hamid, \\ Abid Yaqoob and Muhammad Ahmed Shehzad. Effect of organic fungicides on sooty blotch, flyspeck and quality \\ of apple cv. Banki grown in Rawalakot, Azad Jammu and Kashmir. Pure and Applied Biology. Vol. 7, Issue 1, \\ pp400-406. http://dx.doi.org/10.19045/bspab.2018.70049
}

\begin{tabular}{llll}
\hline \hline Received: 04/01/2018 & Revised: 21/03/2018 & Accepted: 24/03/2018 & Online First: 10/03/2018 \\
\hline \hline
\end{tabular}

\section{Abstract}

Sooty blotch (SB) and flyspeck (FS) is a disease complex which causes the blemishes on skin surface of apple (Malus domestica Borkh) and damages the cosmetic look of fruit in humid temperate areas of the world. Not only it affects the postharvest quality of apple fruits but also reduces the storage life due to increased transpiration. During this study, five different organic fungicides (Ridomil gold, Thiophanate-methyl, Metalaxyl + Mancozeb, Dithane M-45 and Benomyl) at the rate of 5g/l were sprayed on mature and healthy apple trees to control this disease. Fungicides were applied with spray schedule of 15 days interval. Eight sprays were applied from the month of June to September. Results obtained revealed that the application of organic fungicides significantly $(P \leq 0.05)$ reduced the disease incidence of SB and FS as compared to control. Maximum disease control (92.50\%) and minimum $(7.50 \%)$ fruit blotches were recorded with a combined application of Metalaxyl + Mancozeb. Similarly, maximum fruit weight $(140.57 \mathrm{~g})$, and total yield per tree $(28.30 \mathrm{~kg})$ were obtained in plants treated with Metalaxyl + Mancozeb. However, maximum fruit set per tree (299.75) was recorded in plants sprayed with Dithane M-45 as compared to control (160.25). Maximum total soluble solids and total sugars $(12.90 \%, 15.50 \%)$ were recorded in fruits which were sprayed with Benomyl and Dithane M45 , while minimum total soluble solids and total sugars $(10.90 \%, 10.87 \%)$ were recorded in control fruits. Minimum ascorbic acid and titratable acidity $(15.10 \mathrm{mg} / 100 \mathrm{~mL}, 3.65 \%)$ were recorded in fruits which were treated with Benomyl, respectively. Overall, a combined treatment of Metalaxyl + Mancozeb not only gave the best control against SB and FS but also increased the total fruit yield and improved the fruit colour as compared to other treatments. Therefore, it could be further exploited on a commercial scale against SB and FS in future.

Keywords: Ascorbic acid; Disease complex; Malus domestica Borkh; Organic fungicides 


\section{Introduction}

Apple (Malus domestica Borkh) is an important deciduous fruit of temperate region. It belongs to family Rosaceae. The center of origin of apple is Asia, Central Asia, Himalayan regions of India, Pakistan and Western China [1]. Apples are one of the most common fruits consumed on a regular basis by many people in different cultures. They are a significant part of the human diet. Moreover, only for the fruit phenolics consumed in USA, apples provide twenty two percent which makes them one of the largest sources of phenolics [2]. The nutritive value is well known and represents the variable content of proteins, sugar, ascorbic acid, and mineral substances. Sugar content and firmness are important quality attributes that directly influence consumers on purchasing fresh apple fruit. The presence of a variety of nutrients in apple makes it an amazing super fruit. It is not just a treat to eat, but it is also a great fruit for your overall health [3, 4]. In Azad Jammu and Kashmir, apple is successfully grown in districts Poonch, Sudhnoti, Bagh, Muzaffarabad, and Neelum. Commercial varieties of apple grown in Pakistan and Azad Jammu and Kashmir are Kashmiri Amri, Kulu, Sky Spur, Red Chief, Golden Delicious, Red Delicious, Starking Delicious, Star Crimson, Banki, Red Labnani and Royal Gala [5]. Sooty blotch (SB) and Flyspeck (FS) are very serious diseases of apple caused by Schizothyrium pomi and Gloedes pomigena, respectively [6]. SB and FS fungi are ectoparasites growing on the epicuticular wax layer of apples [7]. Several different SB and FS fungi often co-exist in the same orchards and on the same fruit [8]. Symptoms of SB appear as a dark smudgelike blemish on the apple surface. It deteriorates fruit quality other than yield. The olive-grey spots usually cover $80 \%$ of fruit surface; meanwhile, FS develop numerous small, round and black spots on the skin of fruit [9]. The presence of either SB or FS on the apple's surface lowers quality and market value of the fruit [8], even though the SB and FS fungi do not penetrate the cuticle [6]. Although, in late summer, the discrete colonies of FS pathogen (S. pomi) appear and mycelial mats which are only visible with microscope [9]. Fungi which cause the SB complex are categorized into different mycelial types which consist of punctate, ramose, rimate and fuliginous [10]. The climate of Azad Jammu and Kashmir favours vigorous growth, high yield potential, large fruit size with good taste of apple but with inferior cosmetic look due to SB and FS. In the past, many researchers have tried to control these diseases in other parts of the world using different techniques [11-14]. Even organic and inorganic fungicides were also applied under spray programs $[12,15-$ 20]. However, no work has been done on improvement of cosmetic look and overall quality of important cultivars of apple like 'Banki' grown in sub-humid temperate hilly tracts of Azad Jammu and Kashmir. Therefore, this study was designed to determine the effect of organic fungicides on SB and FS of apple grown under Rawalakot conditions.

\section{Materials and methods}

The current studies were carried out in subhumid temperate hilly region of Rawalakot, district Poonch, Azad Jammu and Kashmir. Twenty four (24) apple trees of same age, size and health of cultivar Banki were selected. The experiment was laid out in randomized complete block design (RCBD) with six treatments, repeated four times. Different organic fungicides (Ridomil gold, Thiophanate-methyl, Metalaxyl + Mancozeb, Dithane M-45 and Benomyl) along with water as a control were used at $5 \mathrm{~g}$ per liter concentration at 15 days interval on apple trees at fruit set stage. Data was collected for different parameters such as fruit set per tree, number of fruits affected by blotches, disease control percentage, fruit colour $\left(\mathrm{L}^{*}, \mathrm{a}^{*}, \mathrm{~b}^{*}\right.$ 
values), average fruit weight (g), total weight of fruits per plant $(\mathrm{kg})$, total soluble solids (\%), total sugars (\%), ascorbic acid (mg/100 $\mathrm{mL}$ ) and titratable acidity (\%) using standard methods. Data were subjected to the analysis of variance (ANOVA) and tested for significant differences among treatments by the Least Significant Difference (LSD) test at $(P \leq 0.05)$ using MSTAT-C software.

\section{Results and discussion}

\section{Number of fruit set per tree}

Results given in (Table 1) showed that maximum fruit set per tree was obtained with Dithane M-45 (299.75) followed by Metalaxyl + Mancozeb (273.25), respectively. Whereas the minimum fruit set per tree was obtained with control (160.25) followed by Ridomil gold (193.50) and Benomyl (208.25), respectively. Similar results were also obtained by different researchers in the past when they applied organic fungicides on other fruits as well [12, 18-20].

\section{Total weight of fruits per tree (kg)}

Results regarding total weight of fruits per tree showed that the influence of organic fungicides on fruit yield was statistically significant (Table 1). Maximum fruit yield was recorded on trees that were treated with Metalaxyl + Mancozeb (28.30 kg), while minimum was obtained from untreated trees (12.15 kg). Presumably, fungicides increased yield through increasing fruit holding capacity, reduced fruit drop and by keeping plants healthy. It was also confirmed by the findings of Rosenberger et al. [21] who reported that trees treated with fungicides produced more yield (11.6\%) and higher $(50 \%)$ gross return than untreated trees.

\section{Disease control percentage}

Data regarding disease control percentage showed that Metalaxyl + Mancozeb gave the best control $(92.50 \%)$ as compared to other treatments (Table 1). Disease control percentage of $88.0 \%$ and $82.50 \%$ was observed with Dithane M-45 and
Thiophanate-methyl, respectively. Similarly, $79.50 \%$ and $78.50 \%$ disease control was observed with Ridomil gold and Benomyl, respectively. While the lowest percentage of disease control was recorded in untreated control fruits (7.50\%). Similarly, Brown and Sutton [9] observed that SB was not properly controlled when the spray treatments were beyond 14-days schedule and best control was achieved by Mancozeb concentrate.

\section{Average number of fruits affected by blotches (SB, FS)}

Data pertaining to the number of fruits affected by blotches (SB, FS) showed that different fungicides caused significant reduction in the fruits infected by blotches than control fruits (Table 1). Control fruits showed the highest level of infected fruits (92.50) with SB and FS. Minimum number of fruits affected by SB and FS were recorded on trees those were treated with Metalaxyl + Mancozeb (7.50) followed by Dithane M-45 (12). Results showed that organic fungicides significantly reduced the effect of SB and FS when sprayed at 15 days interval. Similar findings were reported previously by different scientists where they found when applying organic fungicides the incidence of SB and FS can be minimized [17, 20, 21].

\section{Average fruit weight (g)}

Mean values for the average fruit weight showed that the application of Metalaxyl + Mancozeb and Dithane M-45 helped the apple fruits to gain weight as compared to control and other treatments (Table 2). These results clearly showed that different organic fungicides application affected the average fruit weight (g) significantly. These results are in accordance with the findings of Rosenberger et al. [21] who observed that fungicides application minimized the incidence of fungal diseases in sprayed defoliated trees than unsprayed trees. Treated trees with fungicides produced more yield $(11.6 \%)$ and higher (50\%) gross returns than untreated trees. 
Fruit colour $\left(L^{*}, a^{*}, b^{*}\right)$

Mean values for fruit colour $\left(\mathrm{L}^{*}\right)$ showed that Metalaxyl + Mancozeb treated fruits presented maximum (68.50) fruit colour ( $\left.\mathrm{L}^{*}\right)$ values that decreased to 65.25 in Dithane M$45,61.25$ in Thiophanate-methyl, 61 in Benomyl and 60.25 in Ridomil gold treated fruits. While, in control fruits colour $\left(\mathrm{L}^{*}\right)$ value was recorded only 32.50 (Table 2 ). Similarly, mean values for fruit colour $\left(\mathrm{a}^{*}\right)$ showed that the effect of organic fungicides used were highly significant. Maximum fruit colour $\left(\mathrm{a}^{*}\right)$ values were recorded for untreated control fruits $(-3.50)$ that produced fruits of dark colour, while minimum fruit colour $\left(\mathrm{a}^{*}\right)$ value was recorded for trees those were treated with Metalaxyl + Mancozeb (8.50) and presented excellent natural colour of fruits (Table 2). Moreover, mean values of fruit colour $\left(b^{*}\right)$ showed that the effect of organic fungicides used were highly significant. Maximum fruit colour $\left(\mathrm{b}^{*}\right)$ values were recorded for fruits treated with Metalaxyl + Mancozeb (42), while minimum were recorded for untreated control fruits (11) (Table 2). It is evident from these results that organic fungicides improved fruit colour by controlling SB and FS of apples. Many researchers also reported previously that better control of SB and FS blotches by using fungicides application improved the cosmetic appearance of the fruits as well $[12,19,20$, 22].

\section{Total soluble solids (\%)}

Mean values of total soluble solids showed that fungicides significantly affected the total soluble solids (Table 3). Maximum total soluble solids were recorded in fruits treated with Benomyl (12.90\%), while minimum were observed in control fruits (10.90\%). Ridomil gold (11.96\%), Metalaxyal + Mancozeb (11.92\%), Thiophanate-methyl (11.36\%) and Dithane M-45 (11.26\%) showed intermediate levels of total soluble solids. Findings of Hafez and Haggag [23] showed that all foliar sprays of fungicides increased total soluble solids, total sugar, total anthocyanins, while decreasing total acidity, in apple fruits for their best quality when compared with untreated ones.

\section{Total sugars (\%)}

Results regarding total sugars in treated and untreated fruits showed that organic fungicides had significant effect on the total sugars in all the treated fruits (Table 3). It is evident from the results that total sugars increased in those fruits which were treated with fungicides compared to untreated ones. Maximum total sugars were recorded in fruits which were treated with Dithane M-45 $(15.50 \%)$ and minimum were recorded in untreated apple fruits (10.87\%). Hafez and Haggag [23] also reported similar results when they used fungicides as a foliar application. Fungicides treatment increased fruit firmness, total sugars, total soluble solids, total anthocyanins, while decreased the total acidity.

\section{Ascorbic acid (mg/100 mL)}

Results regarding ascorbic acid showed that organic fungicides significantly affected ascorbic acid content (Table 3). Maximum ascorbic acid was recorded in untreated fruits $(18.07 \mathrm{mg} / 100 \mathrm{~mL})$, while minimum was found in Benomyl treated fruits (15.10 $\mathrm{mg} / 100 \mathrm{~mL}$ ). It appeared that application of organic fungicides has more or less similar effect on ascorbic acid and decreased ascorbic acid content compared to control fruits. Ascorbic acid content may be decreased due to more or less effect of fungicides application on fruits and it depends upon climatic conditions and concentration of fungicides. Results of Hafez and Haggag [23] also showed that fruit quality of apple was affected by different concentrations of fungicides applied. Neimczyk et al. [24] found that the quality of apples from fungicides spray was slightly lower or lower than that of control plot. 
Table 1. Effect of different organic fungicides on fruit set per tree, total weight of fruits per tree, disease control percentage and average number of fruits affected by blotches $\left({ }^{\dagger}\right)$

\begin{tabular}{|c|c|c|c|c|}
\hline Treatments & $\begin{array}{c}\text { No. of fruit set } \\
\text { per tree }\end{array}$ & $\begin{array}{c}\text { Total weight of fruits } \\
\text { per tree (kg) }\end{array}$ & $\begin{array}{c}\text { Disease control } \\
\text { percentage }\end{array}$ & $\begin{array}{c}\text { Avg. no. of fruits affected by } \\
\text { blotches (SB, FS) }\end{array}$ \\
\hline Control & $160.25 \mathrm{c}$ & $12.15 \mathrm{~d}$ & $7.50 \mathrm{~d}$ & $92.50 \mathrm{a}$ \\
\hline Ridomil gold & $193.50 \mathrm{bc}$ & $18.00 \mathrm{c}$ & $79.50 \mathrm{c}$ & $20.50 \mathrm{~b}$ \\
\hline Thiophanate-methyl & $219.75 \mathrm{~b}$ & $23.57 \mathrm{~b}$ & $82.50 \mathrm{bc}$ & $17.50 \mathrm{~b}$ \\
\hline Metalaxyl + Mancozeb & $273.25 \mathrm{a}$ & $28.30 \mathrm{a}$ & $92.50 \mathrm{a}$ & $7.50 \mathrm{~d}$ \\
\hline Dithane M-45 & $299.75 \mathrm{a}$ & $23.55 \mathrm{~b}$ & $88.00 \mathrm{ab}$ & $12.00 \mathrm{c}$ \\
\hline Benomyl & $208.25 \mathrm{~b}$ & $16.97 \mathrm{c}$ & $78.50 \mathrm{c}$ & $21.50 \mathrm{~b}$ \\
\hline
\end{tabular}

${ }^{\dagger}$ Any two means in a column not sharing a common letter are significantly different at $(P \leq 0.05)$ using LSD. Each value is the mean of four replicates

Table 2. Effect of different organic fungicides on physical properties of apple fruits $\left({ }^{\dagger}\right)$

\begin{tabular}{|c|c|c|c|c|}
\hline \multirow{2}{*}{ Treatments } & \multirow{2}{*}{ Avg. fruit weight $(\mathbf{g})$} & \multicolumn{3}{|c|}{ Fruit colour } \\
\cline { 3 - 5 } & & L* values $^{*}$ & $\mathbf{a}^{*}$ values & \multicolumn{1}{c|}{$\mathbf{b}^{*}$ values } \\
\hline Control & $83.93 \mathrm{c}$ & $32.50 \mathrm{~d}$ & $-3.50 \mathrm{a}$ & $11.00 \mathrm{c}$ \\
\hline Ridomil gold & $110.08 \mathrm{~b}$ & $60.25 \mathrm{c}$ & $-6.00 \mathrm{~b}$ & $37.75 \mathrm{~b}$ \\
\hline Thiophanate-methyl & $113.70 \mathrm{~b}$ & $61.25 \mathrm{c}$ & $-3.50 \mathrm{a}$ & $37.25 \mathrm{~b}$ \\
\hline Metalaxyl + Mancozeb & $140.57 \mathrm{a}$ & $68.50 \mathrm{a}$ & $-8.50 \mathrm{c}$ & $42.00 \mathrm{a}$ \\
\hline Dithane M-45 & $139.90 \mathrm{a}$ & $65.25 \mathrm{~b}$ & $-6.75 \mathrm{bc}$ & $41.25 \mathrm{a}$ \\
\hline Benomyl & $118.16 \mathrm{~b}$ & $61.00 \mathrm{c}$ & $-4.75 \mathrm{ab}$ & $35.50 \mathrm{~b}$ \\
\hline
\end{tabular}

Any two means in a column not sharing a common letter are significantly different at $(P \leq 0.05)$ using LSD. Each value is the mean of four replicates

Table 3. Effect of different organic fungicides on chemical properties of apple fruits $(\dagger)$.

\begin{tabular}{|c|c|c|c|c|}
\hline Treatments & Total soluble solids (\%) & Total sugars (\%) & Ascorbic acid (mg/100 ml) & Titratable acidity (\%) \\
\hline Control & $10.90 \mathrm{c}$ & $10.87 \mathrm{c}$ & $18.07 \mathrm{a}$ & $6.50 \mathrm{a}$ \\
\hline Ridomil gold & $11.96 \mathrm{ab}$ & $12.87 \mathrm{~b}$ & $15.46 \mathrm{~cd}$ & $4.96 \mathrm{~b}$ \\
\hline Thiophanate-methyl & $11.36 \mathrm{bc}$ & $12.22 \mathrm{bc}$ & $16.57 \mathrm{bc}$ & $5.27 \mathrm{~b}$ \\
\hline Metalaxyl + Mancozeb & $11.92 \mathrm{ab}$ & $11.22 \mathrm{bc}$ & $17.75 \mathrm{ab}$ & $6.05 \mathrm{ab}$ \\
\hline Dithane M-45 & $11.26 \mathrm{bc}$ & $15.50 \mathrm{a}$ & $16.85 \mathrm{ab}$ & $5.50 \mathrm{ab}$ \\
\hline Benomyl & $12.90 \mathrm{a}$ & $12.45 \mathrm{bc}$ & $15.10 \mathrm{~d}$ & $3.65 \mathrm{c}$ \\
\hline
\end{tabular}

${ }^{\dagger}$ Any two means in a column not sharing a common letter are significantly different at $(P \leq 0.05)$ using LSD. Each value is the mean of four replicates 


\section{Titratable acidity (\%)}

Mean values of titratable acidity showed that control fruits presented maximum $(6.50 \%)$ titratable acidity that decreased up to $6.05 \%$ and $5.50 \%$ for Metalaxyal + Mancozeb and Dithane M-45, respectively (Table 3). Thiophanate-methyl and Ridomil gold treated fruits showed $5.27 \%$ and $4.96 \%$, while minimum titratable acidity was recorded in Benomyl treated fruits (3.65\%). It is evident from the results that fungicides spray like Metalaxyl + Mancozeb and Dithane M-45 slightly reduced the ascorbic acid than that of the fruits from control. Niemczyk et al. [24] reported that the quality of apples from fungicides spray like Dithane M-45 was slightly lower or lower than that of fruits from control plots. Hafez and Haggag [23] also found that all foliar sprays of fungicides gave the best results in terms of fruit quality parameters when compared to the control fruits.

\section{Conclusions and recommendations}

It can be concluded that all the treatments of organic fungicides had positive effects on the studied parameters. However, the combined treatment of Metalaxyl + Mancozeb not only increased the number of fruit set per tree, average fruit weight and total weight of the fruits per tree but also improved fruit colour and overall quality. Moreover, it also decreased the blotches (SB, FS) percentage on harvested apple fruits. Therefore, based on the results obtained from the current study, Metalaxyl + Mancozeb can be recommended to be used at commercial scale against SB and FS, to increase total yield and improve quality of apple fruits under Rawalakot conditions.

\section{Authors' contributions}

Conceived and designed the experiment: MJ Ahmed, SZA Shah, Performed the experiment: I Shehzad, A Yaqoob, Analyzed the data: MA Shehzad, N Zahid, Contributed reagents/materials/analysis tools: SZA Shah,
A Hamid, Wrote the paper: I Shehzad, M Maqbool \& N Zahid.

\section{Acknowledgements}

The authors would like to thank the Research Unit of Department of Agriculture, Rawalakot, Government of Azad Jammu and Kashmir for providing the facility of apple orchard to conduct this research study.

\section{References}

1. Muzher BM, Younis RAA, El-Halabi O \& Ismail OM (2007). Genetic identification of some Syrian local apple (Malus sp.) cultivars using molecular markers. Res J Agric Biol Sci 3: 704-713.

2. Vinson JA, Su X, Zubik L \& Bose P (2001). Phenol antioxidant quantity and quality in foods: fruits. J Agric Food Chem 49: 5315-5321.

3. Harsan E, Sestras RE, Somsai PA, Barbos A \& Sestras AF (2006). Research regarding the principal chemical component loss in the apple fruit during storage. Not Bot Hort Agrobot Cluj 34: 106-114.

4. Yankun P \& Renfu L (2006). Improving apple fruit firmness predictions by effective correction of multispectral scattering images. Postharvest Bio Technol 41: 266-274.

5. Ahmed MJ \& Raza M (2005). Effect of pruning and fertilizer application on growth and yield of apple. Sarhad J Agric 21: 193-196.

6. Johnson EM, Sutton TB \& Hodges CS (1997). Etiology of sooty blotch disease in North Carolina. Phytopathol 87: 8895.

7. Batzer JC, Sisson AJ, Harrington TC, Mayfield DA \& Gleason ML (2012). Temporal patterns in appearance of sooty blotch and flyspeck fungi on apples. Microb Ecol 64: 928-941.

8. Batzer JC, Weber RWS, Mayfield DA \& Gleason ML (2016). Diversity of sooty blotch and flyspeck complex on apple in Germany. Mycol Progr 15: 2. 
9. Brown EM \& Sutton TB (1993). Time of infection of Gloeodes pomigena and Schizothyrium pomi on apple in North Carolina and potential control by an eradicant spray program. Plant Dis 77 : 451-455.

10. Groves AB (1933). A study of the sooty blotch disease of apples and casual fungus Gloedes pomigena, Va. Agric Exp Stn Bull 50: 1-43.

11. Cooley DR, Gamble JW \& Autio WR (1997). Summer pruning as a method for reducing flyspeck disease on apple fruit. Plant Dis 81: 1123-1126.

12. Babadoost M, McManus PS, Helland SN \& Gleason ML (2004). Evaluating a wetness-based warning system and reduced-risk fungicides to manage sooty blotch and flyspeck of apple. Hort Technol 14: 51-57.

13. Batzer JC, Stensvand A, Mayfield DA \& Gleason ML (2015). Composition of the sooty blotch and flyspeck complex on apple in Norway is influenced by location and management practices. Eur J Plant Pathol 141: 361-374.

14. Beer M, Brockamp L \& Weber RWS (2015). Control of sooty blotch and black rot of apple through removal of fruit mummies. Folia Hortic 27: 43-51.

15. Brown EM \& Sutton TB (1986). Control of sooty blotch and flyspeck of apple with captan, mancozeb, and mancozeb combined with dinocap in dilute and concentrate applications. Plant Dis 70: 281-284.

16. Gold HJ \& Sutton TB (1988). Past orchard performance as a guide to decisions on use of fungicides to control sooty blotch and flyspeck. Crop Prot 7: 258-266.

17. Fuchs JG, Häseli A \& Tamm L (2002). Influence of application strategy of coconut soap on the development of sooty blotch on apple. In: Proceedings of the $10^{\text {th }}$ International Conference on Cultivation Technique and Phytopathological Problems in Organic Fruit-Growing. FÖKO, Weinsberg, pp. 50-54.

18. Grabowski M \& Wrona B (2004). The effect of various chemical compounds in the control of sooty blotch. Folia Hortic 16: 159-164.

19. Rosenberger DA \& Jentsch P (2006). Effectiveness of lime-sulfur and phosphorous acid for controlling summer diseases on apples. Amer Phytopathol Soc Res Report 61: 024.

20. Mayr U, Späth S \& Buchleither S (2010). Sooty blotch research-a progress report. In: Proceedings of the $14^{\text {th }}$ International Conference on Cultivation Technique and Phytopathological Problems in Organic Fruit-Growing. FÖKO, Weinsberg, pp. 70-77.

21. Rosenberger DA, Engle CA \& Meyer FW (1996). Effects of management practices and fungicides on sooty blotch and flyspeck diseases and productivity of Liberty apples. Plant Dis 80: 798-803.

22. Yue C, Helen H, Jensen DS, Mueller GR, Nonnecke D, Bonnet M \& Gleason ML (2007). Estimating consumer's valuation of organic and cosmetically damaged apples. Iowa State University. Hort Sci 42: 1366-1371.

23. Hafez OM \& Haggag KHE (2007). Quality improvement and storability of Apple cv. Anna by pre-harvest applications of boric acid and calcium chloride. Res J Agric Biol Sci 3: 176-183.

24. Niemczyk E, Olszak RW \& Zajac RZ (1997). The influence of different undergrowth and IPM spray schedules on apple damage, fruit quality and yield. Acta Hortic 422: 154-159. 